\title{
Relationship between Nitrogen Atmospheric Deposition, Discharge and Concentration, and Monthly Change of Those in a River
}

\author{
-A Case Study of Nitrogen Balance Analysis over 16 Years in the Mountainous Tedori \\ River Basin, Japan
}

\author{
Toshisuke Maruyama ${ }^{1}$, Masashi Yoshida ${ }^{1}$, Keiji Takase $^{1}$, Hiroshi Takimoto ${ }^{1}$, Shigeo Ishikawa ${ }^{2}$, \\ Sadao Nagasaka ${ }^{2}$ \\ ${ }^{1}$ Faculty of Environmental Science, Ishikawa Prefectural University, Nonoichi, Japan \\ ${ }^{2}$ College of Bioresource Science, Nihon University, Tokyo, Japan \\ Email: maruyama@ishikawa-pu.ac.jp
}

Received December 12, 2012; revised January 13, 2013; accepted January 25, 2013

\begin{abstract}
The hypothesis that the product of discharge and concentration of nitrogen $(\mathrm{N})$ in river water is equal to the atmospheric deposition was verified in the mountainous basin of the Tedori River in Japan. To verify this relationship, long-term data are required to eliminate the effect of short-term variation of the $\mathrm{N}$ components. The basin has very high mountains, including Mount Hakusan (2702 m altitude), which is covered with deep snow in winter. Therefore, limited data were used for the estimation of the deposition of the entire basin by assuming a linear relationship of altitude. As a result, it was found that the estimated N concentration coincided well with observed concentrations at six sites - the Shiramine and Kuwajima (upper stream), Nakajima (lower stream) and Dainichi dam, Tedori dam and Senami sites (middle stream). The seasonal variation of $\mathrm{N}$ concentrations was low in the snowmelt period and high in autumn through to winter. This was not due to the larger discharge in snowmelt season as it was also found that $\mathrm{N}$ deposition was high in winter and low in spring, which indicated a clear relationship between $\mathrm{N}$ concentration and monthly atmospheric deposition including $\mathrm{N}$ storage in snow pack.
\end{abstract}

Keywords: Nitrogen Balance; Wet and Dry Deposition; Altitude Dependence of Atmospheric Deposition and Precipitation; Nitrogen in Snowpack

\section{Introduction}

The total nitrogen concentration (TNC) in rivers is of great concern because it has a close relationship with water use. River water is used municipally for irrigation and industry, which requires an adequate $\mathrm{N}$ concentration. The $\mathrm{N}$ concentration is greatly affected by agricultural practices, sewage treatment, industrial uses and other environmental components.

This study investigates the relationship between atmospheric (wet and dry) $\mathrm{N}$ deposition (Atdep), precipitation (discharge) and the TNC of a river in a mountainous basin. The relationships have not been investigated previously in mountainous river basins [1], despite their relative simplicity compared with flatland, which usually has complicated land uses with many components such as agricultural land, residential areas and industry.

The $\mathrm{N}$ balance of this study is based on the hypothesis that input is Atdep and output is $\mathrm{N}$ outflow from a river where there is little artificial disturbance. This study is also based on steady state (the total $\mathrm{N}$ in the study area does not change during the investigated period), i.e., it is in a dynamic equilibrium state. This stable state idea is supported by Crocker and Major [2], Tsutsumi [3] and Kira and Shidai [4].

The related components of earlier studies are 1) Atdep or wet deposition was measured worldwide, and the amount of Atdep is $2-20 \mathrm{~kg} \cdot \mathrm{ha}^{-1} \cdot$ year $^{-1}$ worldwide and $\sim 5 \mathrm{~kg} \cdot \mathrm{ha}^{-1} \cdot$ year $^{-1}$ in Japan [5]; and 2) Cleve [6,7] summarized that Atdep is $0.6-2.2 \mathrm{~kg} \cdot \mathrm{ha}^{-1} \cdot \mathrm{year}^{-1}$ in the tundra zone, $6.6-13.0 \mathrm{~kg} \cdot \mathrm{ha}^{-1} \cdot \mathrm{year}^{-1}$ in the subarctic zone and $11.5-21.2 \mathrm{~kg} \cdot \mathrm{ha}^{-1} \cdot \mathrm{year}^{-1}$ in the tropical zone.

Nitrogen outflow was estimated by the product of TNC and river discharge $(Q h)$. The TNC of rivers is investigated worldwide because it affects water use. Hirose [8] reported the concentrations of 34 basins in Japan at 0.01 $2.35 \mathrm{mg} \cdot 1^{-1}$ with an average $0.35 \mathrm{mg} \cdot 1^{-1}$. The river 
discharge is investigated because of the needs of water use and flood control planning, so there is no need list these.

There are many studies on individual components of the $\mathrm{N}$ balance separately, but there is limited research on the relationships between the three components together. This study was conducted using 16 years of continuous data based on $\mathrm{N}$ balance in the mountainous basin of the Tedori river in the Hokuriku region (which receives much precipitation in winter) of Japan. The $\mathrm{N}$ balance three components used were Atdep, TNC and Qh. Using these three components, how the $\mathrm{N}$ concentration of a river is determined was investigated in a mountainous basin.

The purpose of the research was to verify the validity of the relationships between the components by comparing observed and estimated TNC.

\section{Method of Research}

\subsection{Fundamental Concept of Research}

The $\mathrm{N}$ cycle has been studied long term in forests by many ecological and hydrological researchers. Study has focused on the internal $\mathrm{N}$ cycle of forests, in which there are many $\mathrm{N}$ transfers such as those through soil and water, reef and tree trunks and forest animals, all with different life and cycling times. The relationships between the internal components are complicated and have been subject to long term studies from various aspects [9]. This research concerns the external $\mathrm{N}$ cycle. These socalled geographical scientific fields consist of relatively simple components compared with those of the internal cycle. Figure 1 shows the relationships of the internal and external $\mathrm{N}$ cycles in forest.

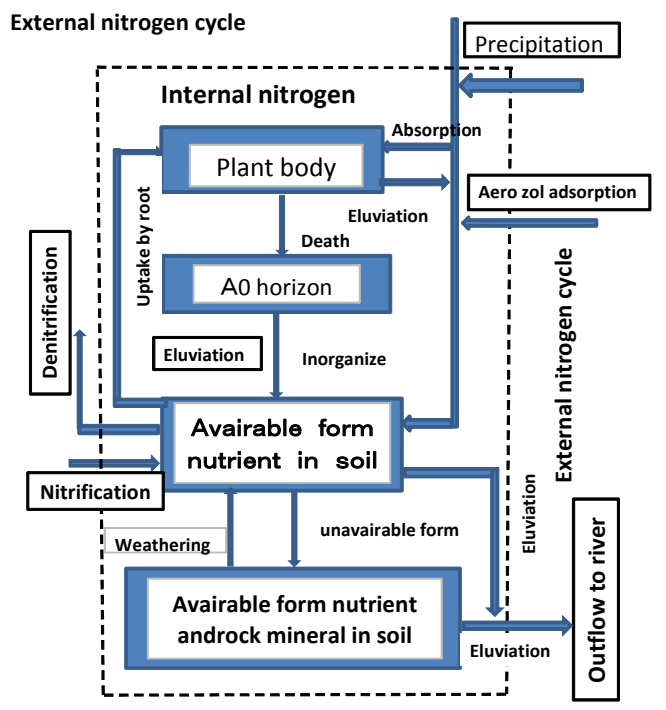

Figure 1. Internal and external nitrogen cycles of a forest (Kira, 1976, revised).
In the external $\mathrm{N}$ cycle, the only related component is that of Atdep, TNC and $Q h$ in unit area without nitrification and denitrification by plants. If a long period is chosen, the following relationship will be satisfied by the mass conservation theorem of $\mathrm{N}$ :

$$
\text { Atdep }=T N C \times Q h
$$

Rewriting Equation (1), the TNC is defined as:

$$
T N C=\text { Atdep } / Q h
$$

where TNC is total nitrogen concentration, Atdep is Atmospheric deposition and $Q h$ is Discharge height.

To verify the relationship of Equation (2), long-term data are required to eliminate the short-term variation or "noise". Here, "noise" means the small changes of $\mathrm{N}$ stored inside the forest. A dynamic stable state of the $\mathrm{N}$ cycle is assumed because of the following reason: If Atdep falls into a forest, the $\mathrm{N}$ will be distributed throughout the soil and water, grass, the trunks and leaves of trees or feed for wild animals. Nitrogen will gradually become saturated in the forest, and the excess nitrogen will then flow out to the river. It is assumed in this study that if this $\mathrm{N}$ cycle continues for a very long period, the flow of $\mathrm{N}$ in the forest approaches a stable state. Based on the above concept, three continuous sets of available data for Atdep, Qh and TNC were selected for 16 years, divided by yearly intervals.

\subsection{Research Site}

The research site is located in the southern part of the Ishikawa prefecture, Japan, which receives a lot of precipitation, especially in winter as snowfall. The research river is the Tedori River which has an $809 \mathrm{~km}^{2}$ basin area as shown in Figure 2. The river originates at Hakusan Mountain, with an altitude of $2702 \mathrm{~m}$, and flows down a ravine between mountains to Turugi point, where the river water flows into the Japan Sea through an alluvial fan. The alluvial fan area has developed fertile agricultural land and important industrial and residential areas, which are supported by water from the Tedori River not only on the surface but also in the ground.

Plant cover was different according to the altitude of the basin. There was a mountainous belt (altitude 400 $1500 \mathrm{~m})$, a semi-high mountain belt (1500 - $2000 \mathrm{~m})$ and a high mountain belt $(>2000 \mathrm{~m})$. The upstream area belongs to the high mountain belt and is dominated by the Hakusan National Park and covered with low height pine trees. In the semi-high mountain belt, high mountain grass is developed and called flower garden. Representative trees Betula Ermanii Chanisso and Abies Mariesii Mast were planted in this area. The former tree was developed in higher areas than the latter. In the mountainous area, high quality beech trees are well developed while Quercus Crispula Blume and Japan Marple are 


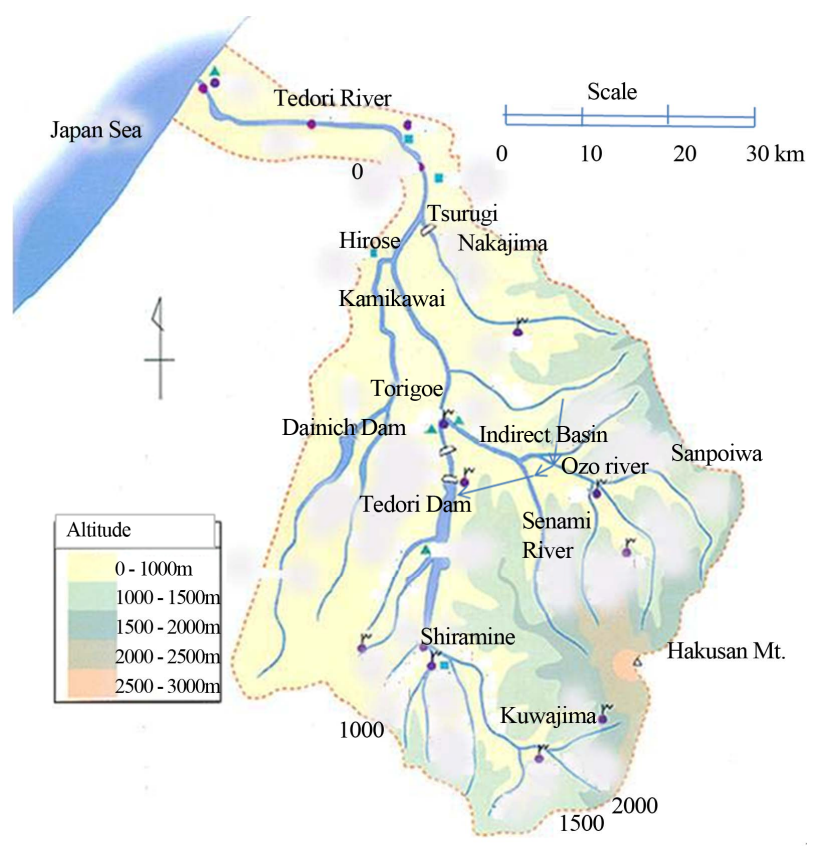

Figure 2. The mountainous area of the Tedori river basin and the observation sites of discharge $(Q h)$ and total nitrogen concentration (TNC).

developed in lowland, and red pine trees on ridges and cedar in valley areas of mountains [10-12].

Table 1 shows the altitude-area relationship every 200 $\mathrm{m}$ at several sites used in this research to evaluate the altitude dependence of precipitation, $Q h$ and Atdep. The mean altitude is calculated by Equation (3).

$$
H c=\frac{1}{A} \sum_{i=1}^{n}(H i \times A i)
$$

Here, $\mathrm{Hc}$ is altitude with $200 \mathrm{~m}$ belt area weighted, $\mathrm{Hi}$ is the center altitude of the belt, $A i$ is the area of the belt, $n$ is the number of belt and $A$ is the total area of the test site.

The Tedori dam basin has the direct and indirect basin from the Senami and Ozo river. In the Dainichi river, discharge was observed at the dam site and TNC was observed at the Kamikawai site located in the lower reaches of the Dainichi dam site. Therefore, these two sites were divided into two columns in Table 1.

\subsection{Atmospheric N Deposition (Atdep)}

The Atdep was investigated at the Taiyougaoka site (altitude $120 \mathrm{~m}$ ) weekly over 16 years by the Research Institute of Ishikawa Environment and Health [13], located 10 $\mathrm{km}$ from the study area. In addition to the wet deposition by precipitation, there is dry deposition of $\mathrm{N}$ from the atmosphere. The average wet deposition of $\mathrm{N}$ based on the 16 years was $15.4 \mathrm{~kg} \cdot \mathrm{ha}^{-1}$, while the dry deposition was 1.2 $\mathrm{kg} \cdot \mathrm{ha}^{-1}[14-16]$. Thus, the total Atdep was estimated at
$16.6 \mathrm{~kg} \cdot \mathrm{ha}^{-1}$. The Atdep showed remarkable seasonal changes, being high in winter and low in summer because of the influence of seasonal wind from Siberia (Figure 3).

\subsection{Discharge Height (Qh)}

River discharge in the Tedori River Basin was investigated at three points-Nakajima (upstream of the Hakusan Head works) the Tedori dam and the Dainichi dam (Figure 2)-by four organizations - the Ministry of Land, Transportation, Infrastructure and Tourism; Hokuriku Electric Power Company; the Civil Engineering Sector of Ishikawa Prefecture; and the Agricultural Division of Ishikawa Prefecture. The discharge of the Nakajima sites was investigated by the first and second organizations. The Nakajima site has $733 \mathrm{~km}^{2}$ of basin area, the direct basin of the Tedori dam site has $247.2 \mathrm{~km}^{2}$ (428.4 $\mathrm{km}^{2}$ including the indirect basin) and the Dainichi dam site has $83.5 \mathrm{~km}^{2}$. Discharge of the Tedori dam site was obtained by subtracting the discharge from the indirect basin of the Senami and Ozo river.

Figure 4 shows the precipitation in the Kanazawa and Nakajima basin, which was already estimated in existing reports [17,18], over 16 years from 1995 . When estimateing the precipitation of the mountainous area, Murodo data (altitude $2455 \mathrm{~m}$ ) were used. Only 151 days in the summer of three years were used as the data were limited because of heavy snowfall.

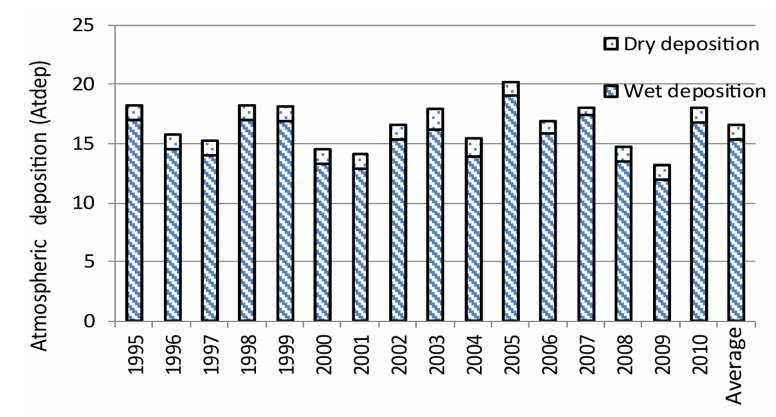

Figure 3. Temporal change of Atdep (wet and dry deposi-

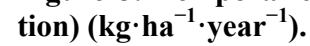

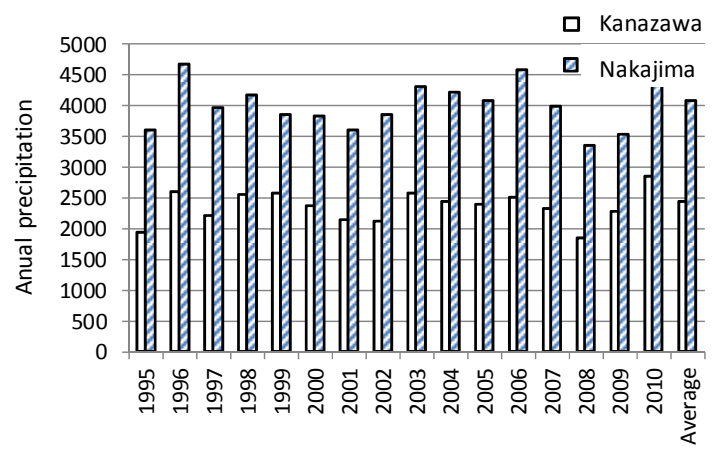

Figure 4. Precipitation at Kanazawa and the Tedori River Mountainous Area (upstream of Nakajima). 
Table 1. Area distribution of each segments of altitude at discharge and water quality observation site.

\begin{tabular}{|c|c|c|c|c|c|c|c|c|c|c|}
\hline \multicolumn{3}{|c|}{ Altitude } & \multirow[b]{2}{*}{ Nakajima } & \multicolumn{2}{|c|}{ Tedori dam } & \multicolumn{2}{|c|}{ Dainich river } & \multirow[b]{2}{*}{ Shiramine } & \multirow[b]{2}{*}{ Senami } & \multirow[b]{2}{*}{ Kuwajima } \\
\hline No. & Range(m) & Center (m) & & $\begin{array}{c}\text { In direct } \\
\text { basin }\end{array}$ & Direct basine & $\begin{array}{c}\text { Dainichi } \\
\text { dam }\end{array}$ & Kamikawai & & & \\
\hline 1 & $100-200$ & 150 & 1009 & & & & & & & \\
\hline 2 & $200-400$ & 300 & 6759 & & & 480 & 2433 & & & \\
\hline 3 & $400-600$ & 500 & 11,106 & 2456 & 2309 & 2248 & 4427 & 628 & & \\
\hline 4 & $600-800$ & 700 & 12,369 & 6039 & 5068 & 2331 & 2768 & 2436 & 971 & 245 \\
\hline 5 & $800-1000$ & 900 & 12,223 & 7455 & 5621 & 2164 & 2439 & 3212 & 1834 & 1147 \\
\hline 6 & $1000-1200$ & 1100 & 10,255 & 7943 & 4345 & 1099 & 1117 & 3127 & 3598 & 1752 \\
\hline 7 & $1200-1400$ & 1300 & 8537 & 7950 & 3862 & 70 & 70 & 3264 & 4088 & 2297 \\
\hline 8 & $1400-1600$ & 1500 & 4805 & 4749 & 1347 & & & 1347 & 3402 & 884 \\
\hline 9 & $1600-1800$ & 1700 & 2292 & 2292 & 569 & & & 569 & 1723 & 460 \\
\hline 10 & $1800-2000$ & 1900 & 1753 & 1753 & 516 & & & 516 & 1237 & 466 \\
\hline 11 & $2000-2200$ & 2100 & 1047 & 1047 & 321 & & & 321 & 726 & 319 \\
\hline 12 & $2200-2400$ & 2300 & 849 & 849 & 529 & & & 529 & 320 & 529 \\
\hline 13 & $2400-2600$ & 2500 & 292 & 292 & 225 & & & 225 & 67 & 225 \\
\hline 14 & $2600-2800$ & 2700 & 11 & 11 & 11 & & & 11 & 0 & 11 \\
\hline \multicolumn{2}{|c|}{ Total area (ha) } & & 73,307 & 42,836 & 24,723 & 8392 & 13,254 & 16,185 & 17,966 & 8335 \\
\hline \multicolumn{2}{|c|}{ Hc (m above sea level) } & & 943 & 1179 & 1052 & 733 & 633 & 1177 & 1359 & 1390 \\
\hline
\end{tabular}

$H c$ : Center of weighted area of altitude belts.

\subsection{Total Nitrogen Concentration}

The TNC data of the Tedori River were published as an Annual Report by the Ishikawa Water Supply Office of the Tedori River [19]. The water quality observations were conducted at the following six sites (Figure 2): Hirose, located near the Nakajima discharge observation site; Tedori dam, located at the No. 1 Hydroelectric Power Generation Station site just downstream of the Tedori dam; Kamikawai, located downstream of the Dainichi dam, Kuwajima; the intake water for the Kuwajima Hydroelectric Power Station, Shiramine, located at the upset stream of the Tedori River; and Senami, the takeoff point from the Senami and Ozo River into the Tedori dam by basin changes.

The TNC was measured by the ultraviolet adsorption method and inorganic $\mathrm{N}$ concentration (Ninorg) was measured by the ion chromatograph method. Organic N (Norg) concentration was obtained from the difference between TNC and Ninorg. The sampling interval was once a month from 1994 to 2003 and four times a year. after 2004 (May, August, November, February). However, at the Tedori dam site the TNC was measured every month after 2004.

Temporal changes of Ninorg and Norg in yearly averages are shown in Figure 5, as an example, at the Hirose site. The Ninorg changes relatively constant between 0.3 and $0.4 \mathrm{mg} \cdot 1^{-1}$, while Norg shows markedly larger deviations, being especially small after 2004. In 2004, the data collection interval changed from every month to four times in a year. In confirmation of this phenomenon, $\mathrm{Ni}$ norg and Norg at the intake water near Hakusan Head (which was measured every month after 2004) also decreased markedly.

Temporal changes of Ninorg were measured at the six aforementioned sites (Figure 6). The Ninorg concentrations at the Shiramine and Kuwajima sites, upstream of the Tedori river, were $0.12-0.25 \mathrm{mg} \cdot l^{-1}$, a markedly low concentration, while the Ninorg concentrations at the Hirose site, in the lower reaches of the river, were higher at $0.33-0.45 \mathrm{mg} \cdot \mathrm{l}^{-1}$. At the Tedori dam and Senami sites, in the middle reaches of the river, values are intermediate between the upstream and downstream sites.

\section{Results and Consideration of Annual TNC Change}

\subsection{Altitude Correction of Atdep}

Areal distribution of $\mathrm{N}$ in Atdep is a big problem in this study area. The Atdep $\mathrm{N}$ may originate mainly from exhaust NOx gas from fossil fuel consumption. Therefore, the Atdep is a function of the distance from the original sites of the NOx production, but the representative distance was not determined. Therefore, the appropriate methods to express these terms in the study area are not available and the areal Atdep $\mathrm{N}$ is assumed to be expressed with the function of altitude.

The study area has high mountains, such as Hakusan 
$(2702 \mathrm{~m})$ that are covered with snow in winter. This results in limited observation data. The Atdep was observed at the Sanpoiwa site at an altitude of $1450 \mathrm{~m}$ beside the Taiyougaoka site. There is no effective measure without using the data of the Taiyougaoka and the Sanpoiwa sites so the hypothesis of altitude dependence is applied as a second best method.

The relationship of the Atdep between the Taiyougaoka and the Sanpoiwa site in the same observation month (June to October for seven years) is displayed in Figure 7. With the assumption that the relationship will be satisfied during all years, the mean wet deposit of the Taiyougaoka site was $15.3 \mathrm{~kg} \cdot \mathrm{ha}^{-1}$ over 16 years, which corresponds with $8.38 \mathrm{~kg} \cdot \mathrm{ha}^{-1}$ at the Sanpoiwa site.

The relationship between the two sites of wet deposition is as follows:

$$
\begin{gathered}
S n=0.543 T n+0.213 \\
\left(R^{2}=0.875, p=0.00197\right)
\end{gathered}
$$

Here, $T n$ is wet deposition at Taiyougaoka. $S n$ is wet deposition at Sanpoiwa.

It is assumed that the Atdep is directly proportional to altitude at the Taiyougaoka and Sanpoiwa sites. Because the Taiyougaoka site is $15.3 \mathrm{~kg} \cdot \mathrm{ha}^{-1}$ at $120 \mathrm{~m}$ altitude and the Sanpoiwa site is $8.38 \mathrm{~kg} \cdot \mathrm{ha}^{-1}$ at $1450 \mathrm{~m}$ altitude, the linear relationship of total Atdep between the two sites is:

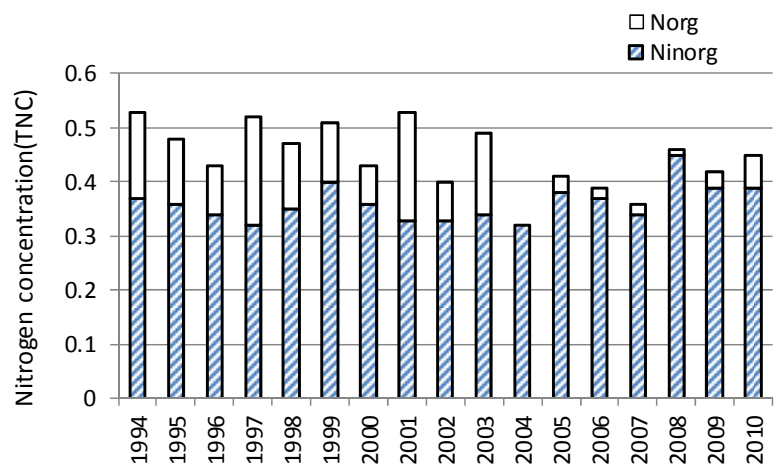

Figure 5. Temporal change of inorganic and organic nitrogen concentration (Ninorg and Norg).

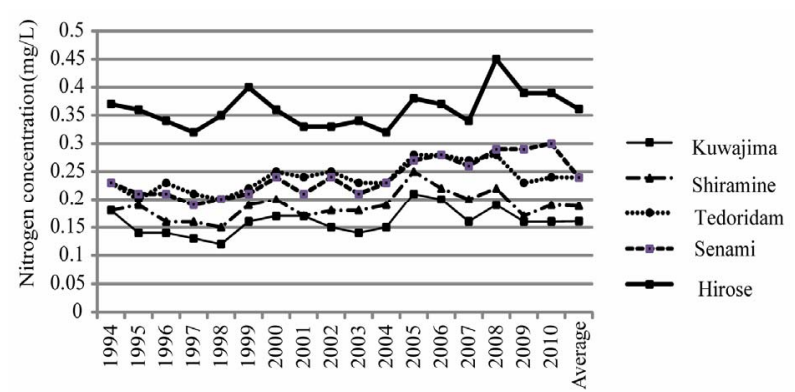

Figure 6. Temporal change of inorganic nitrogen concentration (Ninorg) at various sites $\left(\mathrm{mg} \cdot \mathrm{l}^{-1}\right)$.

$$
\text { DC }=15.98-0.00534 H C
$$

Here, Dc is the Atdep. Hc is the center of the basin defined in Equation (3).

According to Equation (5), the annual average Atdep, based on the data from the Taiyougaoka site, is shown in Table 2. The Nakajima site is 0.692 and is a very important site in this study. The total basin of the Dainichi dam site (Kamikawai) is 0.793 , where there is relatively low altitude, and the Senami and Kuwajima sites, where there is relatively high altitude of 0.557 and 0.546 , respectively.

\subsection{Altitude Correction of $Q h$}

It has already been clarified that the relationship between average altitude and precipitation in the basin is close $[17,18]$. Using the data of Figure 4, the discharge height of the Kanazawa and Nakajima sites was determined by subtracting the evapotranspiration (Complementary relationship) from the precipitation of the Kanazawa and Nakajima sites respectively (Figure 8).

$$
\begin{gathered}
N q=1.153 K q+1406 \\
\left(R^{2}=0.689, p=0.0007\right)
\end{gathered}
$$

Here, $N q$ is $Q h$ at the Nakajima site and $K q$ is $Q h$ at the Kanazawa site.

The relationship between $Q h$ at the Kanazawa and the Nakajima sites was assumed to change proportionally with altitude as well as Atdep. The data used here were a $\mathrm{Qh}$ at Kanazawa of $1603 \mathrm{~mm}$ during 16 years at $7 \mathrm{~m}$ altitude and of $3299 \mathrm{~mm}$ at Nakajima at $943 \mathrm{~m}$ altitude

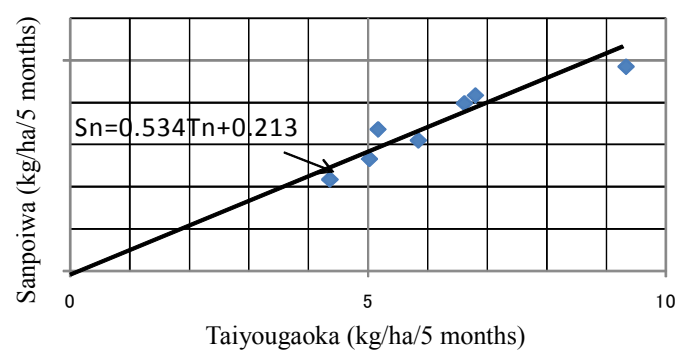

Figure 7. Relationship between the wet deposit of Sanpoiwa (Sn) and Taiyougaoka (Tn).

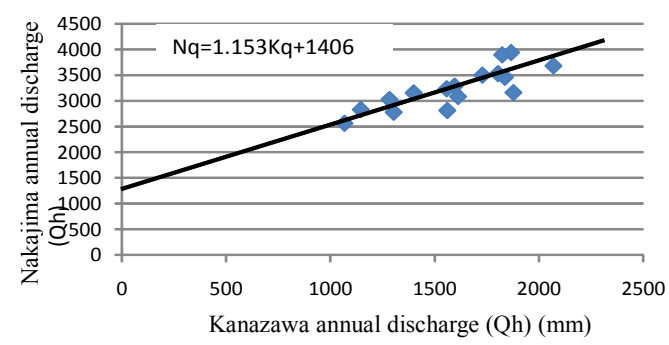

Figure 8. The relationship of discharge $(Q h)$ between the Nakajima and Kanazawa sites. 
(Table 1). Using these data, the relationship between altitude $(H c)$ and discharge height $(Q h)$ is as follows:

$$
Q h=1.757 H c+1594
$$

Table 2 shows the relative discharge height for various sites in the study area based on the Nakajima site. The relative discharge height is 0.886 at the Dainichi dam site, 1.059 at the direct basin of the Tedori dam site (1.128 including the indirect basin). The relative discharge heights at the Kuwajima, Shiramine and Senami sites are shown in Table 2.

\subsection{TNC Load from Farmland and Sewage Effluent Water}

There are small villages in the study area, with a total population of 7330 (2389 households) and farmland of 511 ha, which is mainly paddy fields [20]. Therefore, the $\mathrm{N}$ load from the farmland and sewage effluent should be considered at the lower reaches of the Tedori River (downstream from Torigoe village). The $\mathrm{N}$ load from farmland is estimated by previously reported methods [21-24] and the load from the sewage effluent water was also estimated by existing reported methods $[25,26]$.

The $\mathrm{N}$ cycle in rural areas is expressed in Figure 9 by dividing the inside and outside of the region. As shown in the figure, part of the yield is exported from the region and other parts are consumed inside the region. The yields consumed by the people inside flow to the Tedori River as sewage effluent, and $\mathrm{N}$ not adsorbed by crops also flows out to the Tedori River either as surface or groundwater.

Fertilizer $\mathrm{N}$ use in this area is estimated at $47.15 \mathrm{t} \cdot \mathrm{yr}^{-1}$ (Table 3), and $36 \%$ of rice grown is consumed inside the region and the rest is exported from it. Here, the amount of consumed rice is estimated at $75 \mathrm{~kg} \cdot$ person $^{-1} \cdot \mathrm{yr}^{-1}$ [27], which results in $14.51 \mathrm{t}^{\cdot} \mathrm{yr}^{-1}$ of $\mathrm{N}$ not adsorbed by crops.

Nitrogen in sewage effluent flowing to the Tedori River was estimated at $4.30 \mathrm{t} \cdot \mathrm{yr}^{-1}$ based on $11 \mathrm{~g} \cdot \mathrm{per}-$ $\operatorname{son}^{-1} \cdot \mathrm{d}^{-1}$ and a removal efficiency of $85.2 \%$ by the oxidation ditch method $[25,26]$. Besides the above $\mathrm{N}$ load, 130 head of cattle are breeding in the study area. The $\mathrm{N}$ load from the cattle is estimated at $10.55 \mathrm{t} \cdot \mathrm{yr}^{-1}$ based on 290 $\mathrm{g} \cdot \mathrm{day}^{-1} \cdot \mathrm{head}^{-1}$ [28] and $23.3 \%$ of self-supplied feed [29].

Accordingly, the total $\mathrm{N}$ load without Atdep in the study area is estimated at $29.36 \mathrm{t} \cdot \mathrm{yr}^{-1}$, which flows to the lower reaches of the Tedori River. This load is equivalent to $0.40 \mathrm{~kg} \cdot \mathrm{ha}^{-1}$, which corresponds to $2.4 \%$ of the total Atdep of $16.6 \mathrm{~kg} \cdot \mathrm{ha}^{-1}$.

\section{Verification of Estimated TNC}

First, the accuracy of the altitude correction of the Atdep hypothesis is verified indirectly by comparing the estimated TNC with observed TNC. The next step, using both the altitude correction of $Q h$ based on the Nakajima site and the Atdep based on the Taiyougaoka site, is the estimation of NTC at various sites. After that, the hypothesis of $Q h$ is verified by comparison between observed and estimated TNC. Additionally, the reasonability of $Q h$ estimation based on the Nakajima site was verified by comparing it with observed and estimated $Q h$ at the Tedori dam and the Dainichi dam sites [30].

\subsection{In the Case of No Correction of $Q h$ (Altitude Correction for Atdep Only)}

There was no need to estimate $Q h$ at the Nakajima, Tedori and Dainichi dam sites because $Q h$ was observed, thus it was only necessary to verify the altitude correction of Atdep. The comparison of observed and estimated TNC using only the altitude correction of Atdep is shown in Figure 10 using estimated TNC based on the Taiyougaoka data. The figure shows that the estimated TNC coincides well with observed TNC. The accuracy was expressed with a straight line gradient passing through the origin and relative error [(observed-estimated TNC)/ (observed TNC)]. In addition, total $\mathrm{N}$ at the Dainichi dam site was estimated from the Ninorg site multiplied 1.37 times (average Ninorg over TNC in the Dainichi dam site before 2003) because the TNC was not observed from 2004-2010.

The relative error is 0.034 at the Tedori dam site, 0.012 at the Nakajima site and 0.063 at the Kamikawai site, which coincides with observed TNC. This shows that the altitude correction hypothesis of Atdep is reasonable.

\subsection{In the Case of Altitude Correction for $Q h$ and Atdep}

As the next step, the TNC was estimated at the six sites aforementioned using relative runoff ratios and Atdep in

Table 2. Relative atmospheric deposition (Atdep) and discharge (Qh) at various sites.

\begin{tabular}{|c|c|c|c|c|c|c|c|c|c|}
\hline \multirow[t]{2}{*}{ Site name } & \multirow{2}{*}{$\begin{array}{l}\text { Naka } \\
\text { jima }\end{array}$} & \multicolumn{2}{|c|}{ Tedori dam } & \multicolumn{2}{|c|}{ Dainich river } & \multirow{2}{*}{$\begin{array}{l}\text { Shira } \\
\text { mine }\end{array}$} & \multirow[t]{2}{*}{ Senami } & \multirow{2}{*}{$\begin{array}{l}\text { Kuwa } \\
\text { jima }\end{array}$} & \multirow[t]{2}{*}{ Note } \\
\hline & & In direct basin & Direct basi & Dainich dam & $\begin{array}{l}\text { Kami } \\
\text { kawai }\end{array}$ & & & & \\
\hline Relative Atdep & 0.692 & 0.615 & 0.657 & 0.761 & 0.793 & 0.616 & 0.557 & 0.546 & Taiyougaoka base \\
\hline Relative $Q h$ & 1.000 & 1.128 & 1.059 & 0.886 & 0.833 & 1.126 & 1.225 & 1.242 & Nakajima site base \\
\hline
\end{tabular}


Table 3. Cultivated area and nitrogen fertilizer application rate of various crops.

\begin{tabular}{|c|c|c|c|c|c|}
\hline Villege name & Rice & Soy bean & Vegetable & Orch ard & Total \\
\hline & ha & ha & ha & ha & ha \\
\hline Kawach & 49 & 4 & 5 & 2 & 60 \\
\hline Yoshinotani & 48 & & 4 & 3 & 55 \\
\hline Torigoe & 349 & 2 & 24 & 5 & 380 \\
\hline Oguch & 10 & & 2 & 2 & 14 \\
\hline Shiramine & 0 & & 1 & 1 & 2 \\
\hline Total & 456 & 6 & 36 & 13 & 511 \\
\hline $\begin{array}{c}\text { Average-N } \\
\text { FAR(kg/ha) }\end{array}$ & 78 & 20 & 252 & 184 & 133 \\
\hline $\begin{array}{c}\text { Total-N FAR } \\
\text { (kg/year) }\end{array}$ & 35,568 & 120 & 9062 & 2394 & 47,145 \\
\hline
\end{tabular}

Average-N FAR: Average nitrogen fertilizer application rate; Total-N FAR: Total nitrogen fertilizer application rate.

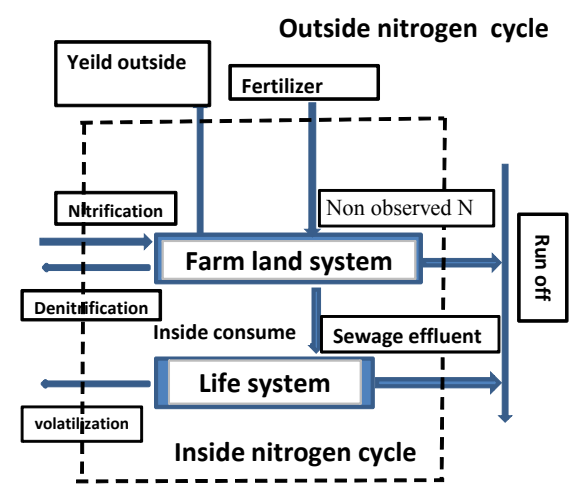

Figure 9. The nitrogen cycle inside and outside of rural areas.

Table 2 based on Equation (1). The estimated TNC over 16 years was compared with observed values at the Hirose, Senami, Kamikawai, Tedori dam, Shiramine and Kuwajima sites (Figure 11). Because the Kamikawai site observed only Ninorg, the TNC was estimated from Ninorg using the correcting ratio of 1.37 times as previously.

The observed discharge at the Dainichi dam site was converted to the Kamikawai site using the relative runoff ratio (Table 2). From this analysis, the estimated values at the Shiramine and Kuwajima sites are relatively higher than observed values. It is possible that $Q h$ was underestimated and Atdep was over estimated. However, the observed and estimated values coincide well with the integrated aspect.

The observed TNC at the Senami site is larger than the estimated TNC. The reason why is as follows: the sampling point is inside the Tedori reservoir and is not adequate because of the high velocity of the indirect Senami Ozo river basin through tunnels; thus, the sampling boat The relative error is 0.086 at the Dainichi dam site in the
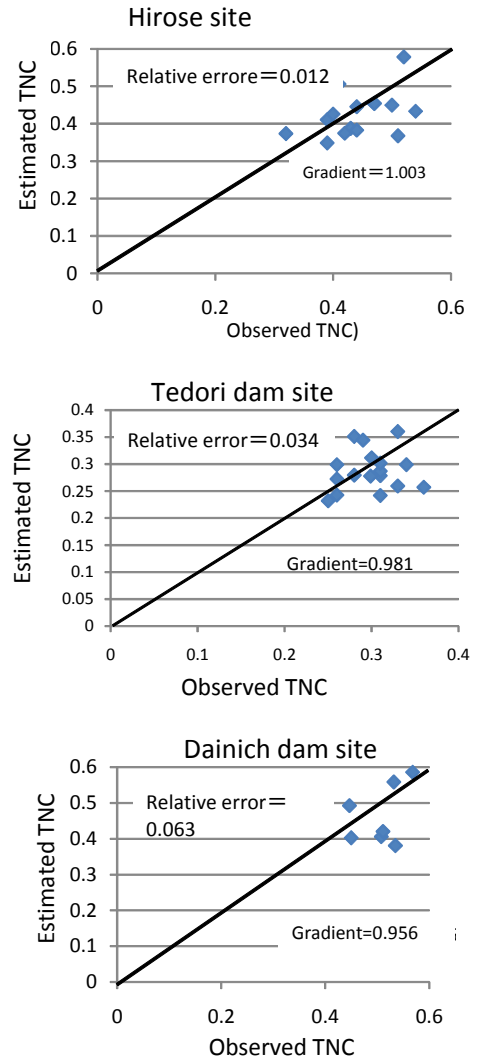

Figure 10. Comparison between observed and estimated nitrogen concentration (TNC) in case of altitude correction applied for only atmospheric deposition Atdep (mg/L).

middle reaches of the river, which coincides well with the observed TNC. There are errors of 0.111 at the Nakajima site and 0.142 at the Tedori dam site. Despite the altitude dependence hypothesis of Qh and Atdep by equation 6 , the estimated and observed TNC coincide well at various sites, which show the procedure is reasonabledoes not approach the takeoff point of water correctly.

\subsection{Relationship between Estimated and Observed Discharge Height}

\subsubsection{The Dainichi Dam Site}

The estimated $Q h$ at the Dainichi dam site was estimated based on the Nakajima $Q h$ (relative discharge coefficient, $0.886)$. To confirm the validity of the procedure, the observed and estimated $Q h$ were compared (Figure 12). Results coincide well with the relative error 0.032 , gradient (coefficient) of the straight line 0.997 .

\subsubsection{The Tedori Dam Site}

A comparison was conducted between observed and estimated $Q h$ by applying altitude correction (relative discharge coefficient 1.05). The relationship coincides well (Figure 12) with a relative error of 0.052 and a gradient 
(coefficient) of straight line 1.054. In this case, the observed discharge at the Nakajima site used data from the Ministry of Land, Infrastructure, Traffic and Tourism because the takeoff $Q h$ from the Tedori dam site was observed by the same Ministry. The number of observed data were limited because the data by the Ministry at the Nakajima site were limited.

\section{Analysis of Monthly Ninorg Change}

\subsection{Monthly Change of Nitrogen Concentration}

The monthly change of Ninorg at the Hirose site, every month for nine years during 1995-2003, is shown in Figure 13. The figure shows very clearly that the monthly change is lowest in June and highest from January to March. This was observed at the other six sites investigated and in the TNC. It is considered that the Ninorg or TNC decreased because of the $Q h$ increase in the snow melting season even if the $\mathrm{N}$ load input was constant.

\subsection{Monthly Change of Nitrogen Load}

Figure 14 shows the monthly change of $Q h$ at the Nakajima site during 1995-2003. The $Q h$ in April is re markably large compared with other months, especially in October. However, $\mathrm{N}$ loads were multiplied by $\mathrm{Qh}$ and $\mathrm{Ni}$ norg were higher in winter and lower in summer. Thus, the high concentration in Figure 14.

April to June was not explained by the high $Q h$ in snow melting season.

\subsection{Monthly Change of Atdep (Wet Deposition)}

The monthly change of Atdep at the Taiyougaoka site is shown in Figure 15 and shows that the concentration is higher in winter (November to March), and lower in summer (April to October).

\subsection{The Relation between Atdep and Ninorg}

The relationship between Atdep and Ninorg of a monthly
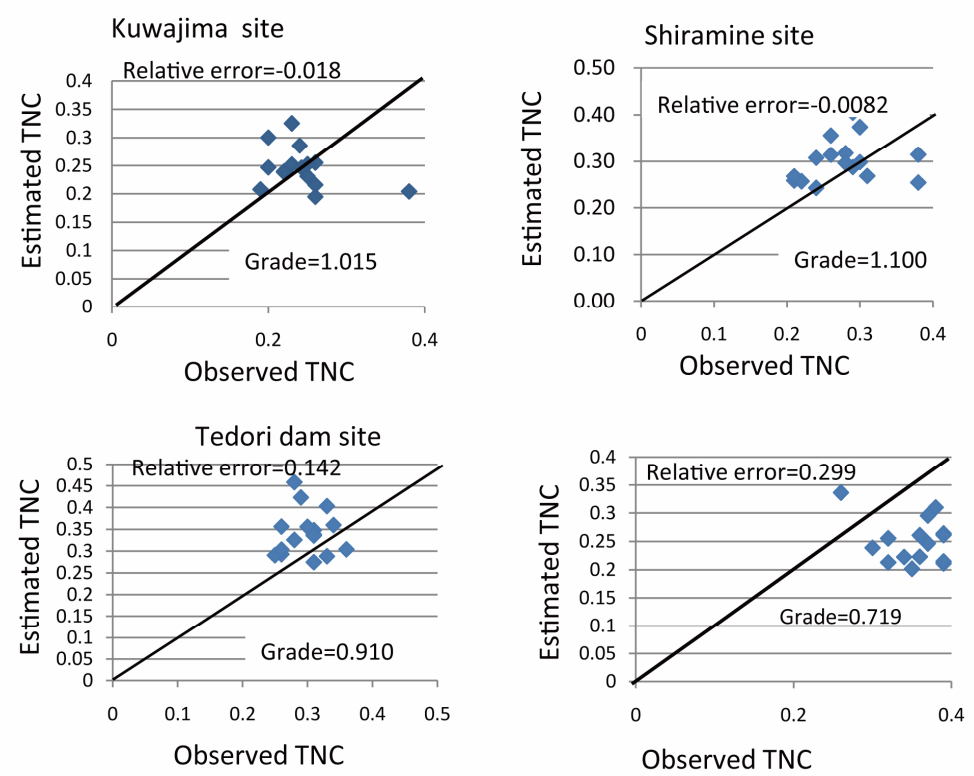
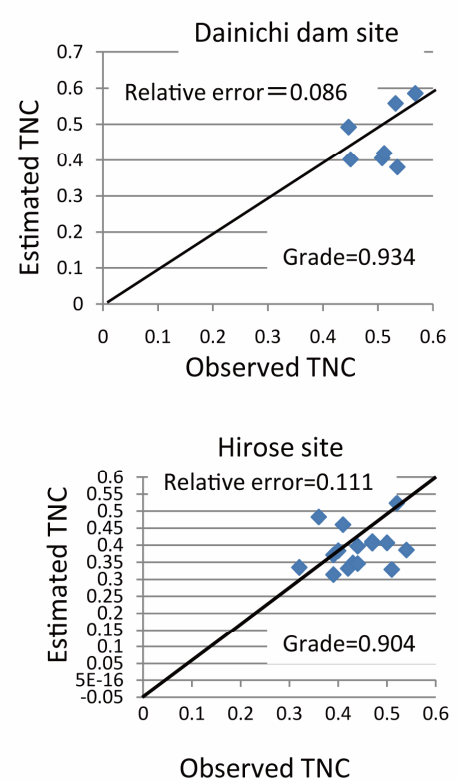

Figure 11. Comparizon between observed and estimated nitrogen concentration (TNC) in case of altitude correction applied for both discharge $(Q h)$ and atmospheric deposition (Atdep).
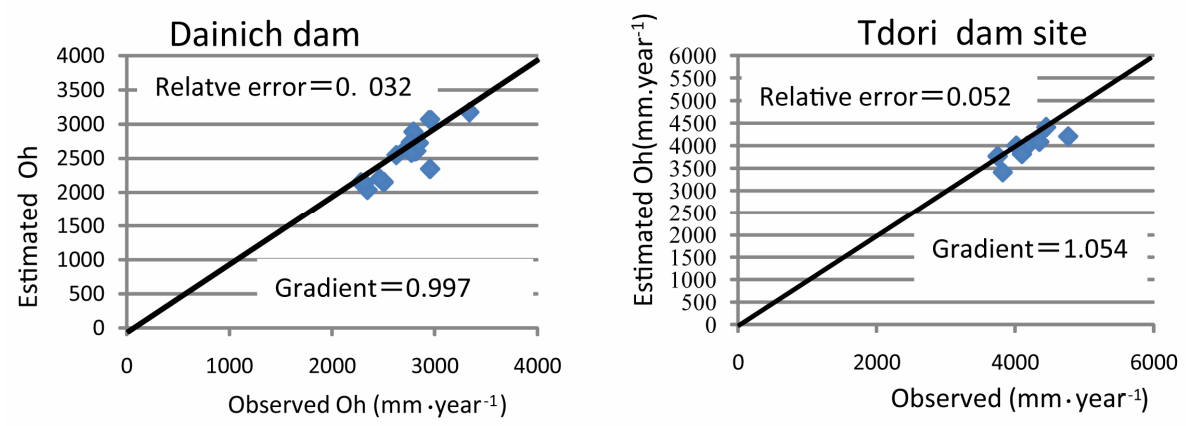

Figure 12. Comparison between estimated and observed discharge hight $(Q h)$ based on Nakajima site. 


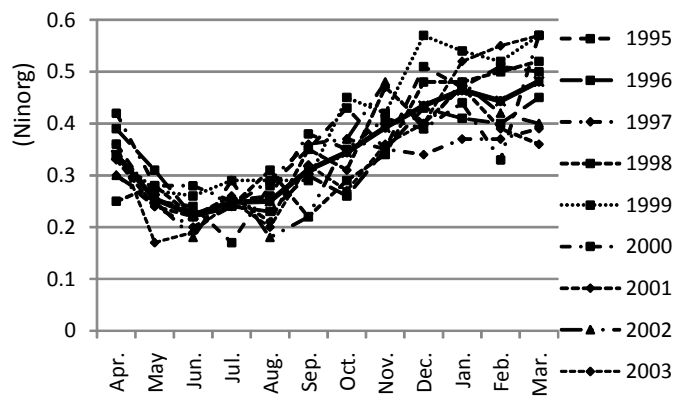

Figure 13. Monthly change of inorganic nitrogen concentration (Ninorg) at the Hirose site $\left(\mathrm{mg} \cdot \mathrm{l}^{-1}\right)$.

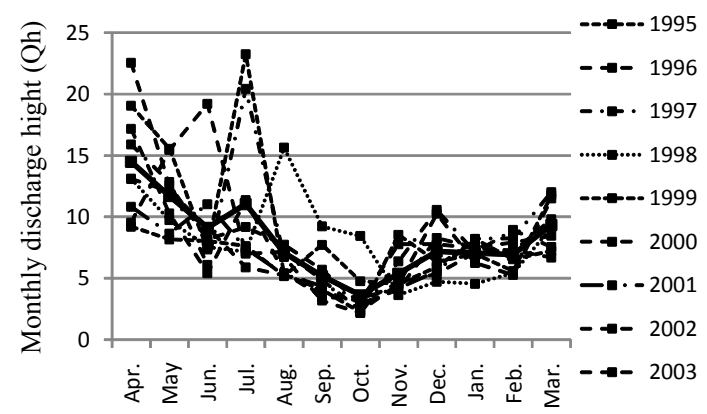

Figure 14. Monthly change of discharge height $(Q h)$ at the Nakajima site $\left(\mathrm{mm} \cdot \mathrm{day}^{-1}\right)$.

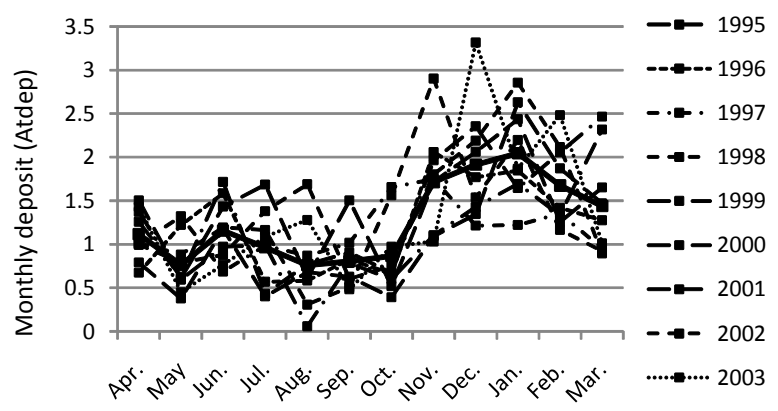

Figure 15. Monthly change in wet deposition at the Taiyougaoka site $\left(\mathrm{kg} \cdot \mathrm{ha}^{-1}\right)$.

average over nine years is shown in Figure 16. The relationship is expressed by the following experimental formula:

$$
\begin{aligned}
\text { TNC } & =0.273+0.149 \text { Atdep } \\
\left(R^{2}\right. & =0.603, p=0.003)
\end{aligned}
$$

Here, Atdep is the monthly average wet deposition and TNC is the monthly average total nitrogen concentration.

In case of organic nitrogen concentration

$$
\begin{aligned}
\text { Ninorg } & =0.145+0.159 \text { Atdep } \\
\left(R^{2}\right. & =0.648, p=0.0016)
\end{aligned}
$$

Equation (8) and Figure 16 show the very clear relationship with some deviation between monthly Atdep and
TNC. Because of the snow pack in winter despite heavy precipitation, the decrease of $Q h$ and increase of Atdep result in high TNC in the winter season. This fact shows TNC in river strongly depend on monthly Atdep. In case of inorganic nitrogen concentration, The relationship is expressed Equation (9) which is quiet similar with TNC case.

\subsection{Relation Snow Storage (pack) with $T N C$ in River}

In winter season, sow pack contain $\mathrm{N}$ within water. Beginning of snow falling season (Oct-Jan), TNC in the river keeps relatively low concentration because $\mathrm{N}$ in Atdep stored in the accumulating snow pack, while snow melting season (Jan-April), the TNC in the river increase because $\mathrm{N}$ in the snow melting water flow out to the river even if Atdep decreased. Figure 17 shows this hysteresis phenomenon as hatched area as average values during 9 years (1995-2003) which investigated TNC in every month. $\mathrm{N}$ stored in snow pack should be express as Figure 17 in every years investigated. But our research did not conducted the analysis because TNC data was not observed sufficient frequency. If conducted more frequent TNC investigation, this method may be effective for estimation of $\mathrm{N}$ stored in sow pack.

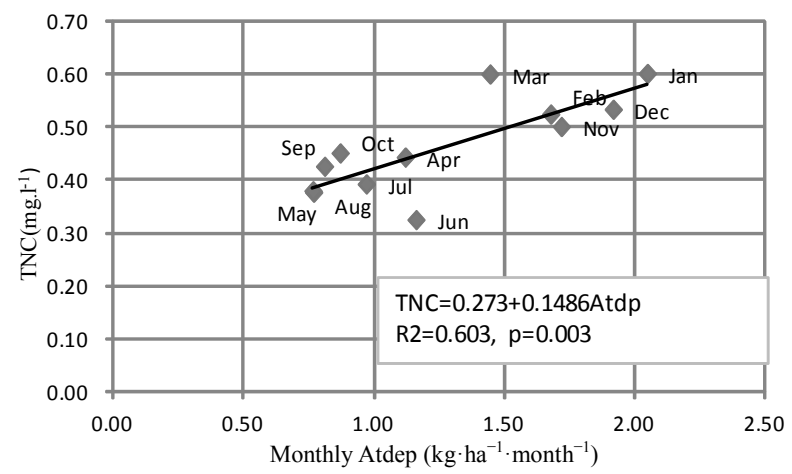

Figure 16. The relationship between TNC and Atdep in monthly average.

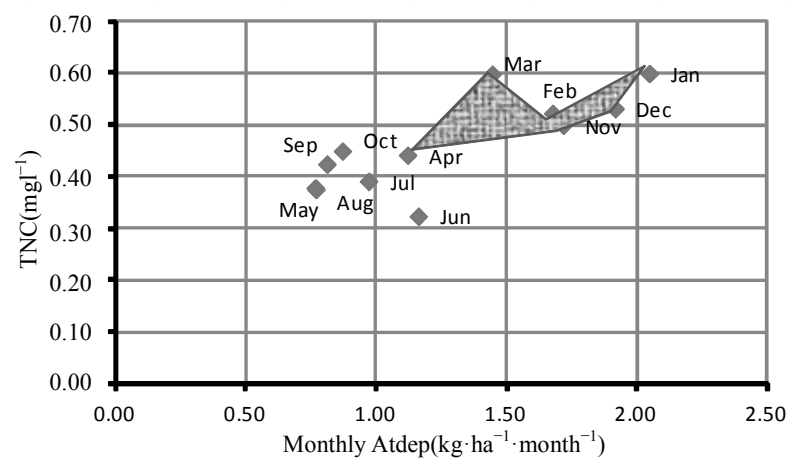

Figure 17. Snow storage effect on TNC-Atdep relationship. 


\section{Conclusions}

For the mountainous Tedori River Basin, research on the relationships between Atdep, Qh and TNC of river water and $\mathrm{N}$ balance analysis was conducted. As a fundamental concept of the research, the external $\mathrm{N}$ cycle of the mountainous basin was chosen over the internal, because the number of components can be reduced, resulting in a simpler $\mathrm{N}$ cycling system despite the long-term data required. Fortunately, Atdep data was measured during 16 years at the Taiyougaoka site, $Q h$ data was measured at the Nakajima, Tedori dam and Dainichi dam sites for 35 years, and TNC was measured at six sites in the basin for 35 years. Therefore, the analysis was conducted during 1995-2010, with the three components of Atdep, Qh and TNC commonly applied.

Expressing the components in a large spatial area is a big problem because it cannot be observed during heavy snowfall. Therefore, the Atdep in the basin was estimated by the altitude dependence hypothesis using the observed data of the Taiyougaoka and Sanpoiwa sites, which were limited to seven years of only the summer season. The $Q h$ in the basin of the observed sites also assumed the altitude dependence hypothesis from the relationship between the Kanazawa and Nakajima sites.

The reliability of this research was confirmed by comparison between observed and estimated TNC. The TNC was estimated by the ratios between Atdep over Qh estimated by Equation (1) at various sites.

The estimated and observed TNC coincide well at six sites distributed over the entire basin; the Hirose site at the lower reaches of the river, the Kuwajima and Shiramine sites at the upper reaches, and the Kamikawai, Senami and Tedori dam sites at the middle reaches. This result shows that the research is reasonable despite the general hypothesis of altitude dependence for Atdep and $Q h$. In addition, the estimation accuracy of $Q h$ was confirmed by the comparison between estimated and observed $Q h$ at the Tedori dam and Dainichi dam sites.

On the other hand, the monthly change of Ninorg was low in snow melting season and high in the winter season. To analyze this phenomenon, the hypothesis that a lot of Qh during snow melting season caused low the Ninorg was disproved. It was found that the Atdep was low in summer but high in winter meaning that the monthly Atdep and Ninorg in the river had a close relationship. This relationsip recognized between TNC and Atdep. Finally amount of $\mathrm{N}$ stored in snow pack expressed using relationship between TNC and Atdep.

The TNC of the Tedori River was low compared with rivers on the Pacific Ocean side of Japan because it has a lot of precipitation and less Atdep owing to the high mountains. In addition, although nitrification and denitrification were not considered, the effect of these components was not great because the reliability of this research was confirmed.

The assumption of stable state of $\mathrm{N}$ flow in the basin was important in this study. This assumption was, in other words, called $\mathrm{N}$ saturation which was also recognized by Ohrui, Mitchel and Iwatsubo [31-33].

\section{Acknowledgements}

We sincerely thank the Ishikawa Prefecture for providing valuable data. We also express thanks to the co-researchers of a study entitled "Normal hydrologic cycle as a core of irrigation water in the Tedori River basin" at Ishikawa Prefectural University, supported by the Ministry of Agriculture, Forests and Fishery, for many valuable comments.

\section{REFERENCES}

[1] G. Iwatubo, N. Tokuch and Y. Nakagawa, "Rain and Forest Runoff-Water Chemistry, the 30 Years Change in the Amount of Dissolved Elements in Rain Water, Input and Output Budget of Elements in Rain and Runoff Water, and the Extensive Regional Change of Runoff Water Chemistry," Japanese Journal of Environmental Toxicology, Vol. 39, No. 2, 1997, pp. 63-71.

[2] R. L. Crocker and J. Major, "Soil Development in Relation to Vegetation and Surface Age of Glacier Bay, Alaska," Journal of Ecology, Vol. 43, No. 2, 1995, pp. 427-448. doi:10.2307/2257005

[3] T. Tsutsumi, "Effect on Soil Characteristics by All Cutting of Tree and Sustainable Forest," Forest Experimental Station Report of Kyoto University, Kyoto, 1963, pp. $37-$ 64.

[4] T. Kira and T. Shidai, "Primary Production and Turnover of Organic Matter in Different Forest Ecosystem of Western Pacific," Japanese Journal of Ecology, Vol. 7, 1967, pp. 70-87.

[5] Y. Tsukamoto, "Forest Hydrology," Buneido Ltd., 1992.

[6] Tsutsumi, "Material Cycle in Forest," Tokyo University Publishing Ltd., 1987, p. 51.

[7] T. Tsutsumi, "Forest Ecology," Asakura Ltd., 1989, p. 150.

[8] A. Hirose, G. Iwatubo and T. Tustusmi, "Study on RunOff Water Chemistry in Japanese Forest (1)," Forest Experimental Station Report of Kyoto University, Vol. 60, 1988, pp. 162-173.

[9] G. Iwatubo, "Forest Ecology," Buneido Ltd., Vol. 116, No. 121, 1996, pp. 172-177.

[10] Shiramine, "Histry of Shiramine," Vol. 1, 1961, pp. 1820.

[11] Oguch, "Histry of Oguch," Ishikawa Prefecture, Vol. 1, 1978, pp. 66-74.

[12] Construction Bureau of Hokuriku Region, "Kanazawa Office of Construction Works, History of Flood Control," 1985, pp. 13-15.

[13] Ishikawa Prefecture, "Investigation Report on Environment and Air. 2006-2010," Research Institute of Ishikawa 
Environment and Health, 2007-2011.

[14] Japanese Association of Environment, "Forth Report of Acid Rainfall in Japan 2005, Environment Research Committee," Journal of Environmental Laboratories Association, 2007, p. 47.

[15] Japanese Association of Environment, "Forth Report of Acid Rainfall in Japan, 2006, Environment Research Committee," Journal of Environmental Laboratories Association, 2008, p. 63.

[16] Japanese Association of Environment, "Forth Report of Acid Rainfall in Japan, 2007," Journal of Environmental Laboratories Association, 2009, p. 63.

[17] F. Noto, T. Maruyama, Y. Hayase, H. Takimoeo and K. Nakamura, "An Evaluation of Snow Storage Depth in the Tedori River Basin Using Tank Model, Trans." Japan Society Irrigation and Drainage Engineering, Vol. 268, 2010, pp. 31-37.

[18] F. Noto, T. Maruyama, H. Takimoto, K. Nakamura and T. Onishi, "Evaluation of Water Resources by Snow Storage Using Tank Model in the Tedori River Basin in Japan," Paddy and Water Environment, Vol. 11, No. 1-4, 2011, pp. 113-121.

[19] Ishikawa Water Supply Office of Tedori River, "Annual Report of Water Quality, 1976-2010,” Ishikawa Water Supply Office of Tedori River, 1977-2011.

[20] Hokuriku Regional Agricultural Administration Office, "Annual Report of Agriculture, Forestry and Fishery of Ishikawa Prefecture 2004-2005," 2006.

[21] T. Maruyama, I. Hashimoto, K. Murashima, H. Takimoto and D. Nakade, "Assessment for Nitrogen Pollution Loads from Farmland, Japan, by Objective Yield and Standard Fertilizer Usage," Paddy and Water Environment, Vol. 7, No. 2, 2009, pp. 151-159. doi:10.1007/s10333-009-0157-y

[22] T. Maruyama, F. Noto, K. Murashima, I. Hashimoto and K. Kitada, "Analysis of the Nitrogen Pollution Lord Potential from Farmland in the Tedori River Alluvial Fan Areas in Japan," Paddy and Water Environment, Vol. 8, No. 3, 2010, pp. 293-300. doi:10.1007/s10333-010-0202-x

[23] T. Maruyama, H. Takimoto, I. Hashimoto, D. Nakade and K. Murashima, "Evaluation of Nitrogen Load Potential from Agricultural Land. By Objective Yield and Standard Fertilizer Usage Association of Upland Agriculture Promotion of Japan," Upland Agriculture, Vol. 615, 2010, pp.
$1-11$.

[24] T. Maruyam, F. Noto, K. Murashima, I. Hashimoto and K. Kitada, "Analysis of the Nitrogen Pollution Load Potential from Farmland on the Tedori River Alluvial Fan Areas," Paddy and Water Environment, Vol. 8, No. 3, 2010, pp. 293-300. doi:10.1007/s10333-010-0202-x

[25] T. Maruyama, F. Noto, T. Takahashi, T. Tsuchihara and T. Tanaka, "Analysis of Nitrogen Pollution Load by Domestic Waste Water Treatment in the Tedori River Alluvial Fan Areas, Trans." Japan Society Irrigation and Drainage Engineering, Vol. 269, 2010, pp. 113-119.

[26] T. Maruyama, F. Noto, T. Takahashi, K. Nakamura and T. Onishi, "Assessment of Environmental Nitrogen Pollution Load Potential from Sewage Treatment Water in the Tedori River Alluvial Fan Area, Japan," Paddy and Water Environment, Vol. 9, No. 2, 2011, pp. 267-274. doi:10.1007/s10333-010-0248-9

[27] Ministry of Agriculture, Forestry and Fishery, "Investigation on Rice Consume," 2012. http://www.maff.go.jp/j/press/shokusan/keikaku/080522. html

[28] Y. Sasaki, "Domestic Animal Physiology," Yokendo Ltd., 2000, p. 249.

[29] Ministry of Agriculture, Forestry and Fishery, Feed Situation, "Domestic Animal Division and Food Safety Management Division," 2012.

http://www.maff.go.jp/j/chikusann/sinko/l-siryo/pdf/1205 meguru.pdf

[30] T. Maruyama, M. Yoshida, K. Takase and H. Takimoto, "Research on Nitrogen Balance in the Mountainous Tedori River Basin of Japan," Journal of Japan Society of Hydrology and Water, 2013.

[31] M. J. Mitchell, G. Iwatubo, R. Ohrui and Y. Nakagawa, "Nitrogen Saturation in Japanese Forest: An Evaluation," Forest Ecology and Management, Vol. 97, No. 1, 1977, pp. 39-51. doi:10.1016/S0378-1127(97)00047-9

[32] K. Ohrui and M. J. Mitchll, "Nitrogen Saturation in Japanese Forested Watersheds," Ecological Applications, Vol. 7, No. 2, 1997, pp. 391-401.

[33] G. Iwatubo, "Natural Purification Function in Forest (Natural Purification Function)," Soomiya Isao, Gihoodo Ltd., 1990, pp. 36-61. 